\title{
ICHTYOFAUNA AT CIJALU RIVER, CILACAP REGENCY CENTRAL JAVA PROVINCE, INDONESIA
}

\author{
AGUS NURYANTO, DIAN BHAGAWATI, M. NADJMI ABULIAS and INDARMAWAN \\ Faailtyof Bidoy, Jenderal Saedirman Univesity, Purwoketo53122, Indonesia
}

Received 22 January 2014/ Accepted 21 June 2016

\begin{abstract}
ABST RACT
Cijalu River is located in Western Cilacap Regency of Central Java Province. The river runs through forestry, housing and farming areas. This condition leads to a prediction that the river has been altered on its physico-chemical characteristics causing the river to be inhabited by a variety of fish species. This study aimed to collect data about fish species inhabiting Cijalu River and its distribution. A survey method has been done with clustered random sampling technique. The river was divided into three different areas, i.e. upper-, middle- and downstreams. Species diversity was measured as the number of species, while distribution was measured as the presentation of fish species in each site. Nineteen fish species of 10 families were identified from Cijalu River. The 10 families were Anabantidae, Bagridae, Balitoridae, Channidae, Cichlidae, Cyprinidae, Loricariidae, O sphronemidae, Poecilidae and Sisoridae. Cyprinidae was the family having the highest number of species ( 6 species), followed by Bagridae ( 3 species), Channidae ( 2 species) and 0 sphronemidae (2 species). The remaining respective families were represented by one species. A complex pattern of fish distribution was observed during the study. Glyptdharax platypognand Chamagacanere only found at the upper-streams, while Amabas testudimas was obtained in downstreams. The other remaining species could be observed either from the middle to downstreams, or even from upper- to downstreams. Different pattern of species distribution could be caused by physico-chemical characteristics variation from upper to lower parts of the river, especially water velocity and substrate types.
\end{abstract}

Keywords: Cijalu River, distribution, diversity, fish

\section{INTRODUCTION}

D iversity indicates the presence of species at certain ecosystem. In macrotaxonomy, diversity measurement is a measure of number of species in an area, whereas in ecology, diversity is represented by species number and its abundances. High species diversity proves that an ecosystem is in an equilibrium state and plays important role in keeping ecosystem in an equilibrium condition. According to Odum (1971) high diversity is shown by no dominant speciesin an ecosystem.

Biodiversity is an integral part of nation development after Brundtland report was first published in 1987 (UNEP 1987). High support of international community on that report and followed by global consultation has led to the establishment of the Convention on Biological D iversity in 1994, which provides guidance related

\footnotetext{
*Corresponding author: anuryanto2003@ yahoo.com
}

to global issue on biodiversity and biodiversity initiative (Nguyen \& D eSilva 2006).

In general, biodiversity initiative focused on terrestrial ecosystem. However, at present days, aquatic ecosystem becomes among the most discussed topics, especially about coral reef and wetlands ecosystems. Later on, researchers are also interested to study biodiversity aspect of freshwater ecosystem including freshwater fish diversity (Nguyen \& De Silva 2006). Previous report showed that a total of 13,000 freshwater fish species have been described and belong to 2,513 genera (D udgeon $\star$ tal. 2006; Leveque $\boldsymbol{e}$ al. 2008).

The majority of freshwater fish species inhabit tropical areas, mainly in Asia (Nguyen \& De Silva 2006). Asia harbors approximately 121 freshwater fish families, higher than those in freshwater ecosystems in Africa and Latin America which have only 50 and 55 fish families, respectively. On species level, 28 up to $32 \%$ of the 13,000 described freshwater fish species were 
recorded from Asia with approximately 462 spesies are threatened. The number is equivalent to $17.5 \%$ of total number of threatened species in the world (Leveque $\notin \mathrm{al}$. 2008). A sum of 66 species were critically endangered or endangered and 32 species of them belong to Cyprinid. Indonesia is among 12 Asian countries with the highest number of threatened fish species (Nguyen \& D e Silva 2006).

High diversity of fish species in Asia is especially found in big rivers and their floodplains (Welcomme 2000; CBD 2003; Coates \&al. 2003). In detail, Asia's freshwater fish is dominated by Cyprinid group ( $\pm 1,000$ spesies) and followed by Balitoridae and Cobitidae ( \pm 400 species, recently, Balitoridae is divided into Balitoridae, Gastromyzontidae, Ellopostomatidae, Vaillantellidae, Barbuccidae, Serpenticobitidae and Nemacheilidae; while Cobitidae becomes Cobitidae and Botiidae (Kottelat 2012); G obiidae (300 species), catfishes Bagridae ( \pm 100 species) and O sphronemidae (85 species) (Nguyen \& De Silva 2006). Specifically, Kar \& al. (2006) also reported that Cyprinidae is a dominant freshwater fish family in India.

Previous studies reported freshwater fish diversity in Africa (Albaret \& al. 2004; Leveque 1997; Harrison \& Whitfield 2006) and Europe (Collares-Pereira \& al. 2002). Several studies had also been done in Indonesia, however, those studies were mostly performed outside of Java; such as in Kalimantan (Haryono 2004; Sulistyarto đal. 2007) and Sumatera (D uya 2008). Studies in smaller rivers in Java have also been done in Cileumeuh and Cikawung Rivers. A study in Cileumeuh River found a total of 22 fish species within 10 families. In Cileumeuh River, Cyprinidae was the speciose family with 10 species and followed by Bagridae with four species (Nuryanto \& al. 2012). Nuryanto \& al. (2015) also recorded a total of 19 species and nine families from Cikawung River.

Cijalu River is located in Western Cilacap Regency, Central Java Province. Administratively, this river belongs to Majenang District with its headwater located in Padontelu Mountains. Cijalu River empties into Cileumeuh River. Cijalu River belongs to Citanduy Watershed together with Cileumeuh and Cikawung Rivers. There have been no data on fish diversity and its distribution at Cijalu River. In addition to the fact that Cijalu River is subjected to several impacts from forestry, farming and house waste which alter the physico-chemical characteristics of the river, Cijalu River is overfished. Therefore, it is important to study fish diversity at Cijalu River to develop database on freshwater fish species in Banyumas Region which is important for further study, such as conservation strategy. This study aimed to collect data on fish diversity and distribution at Cijalu River, Cilacap Regency.

\section{MATERIALS AND METHODS}

Clustered random sampling technique was performed by dividing Cijalu River into three clusters i.e. upper-, middle- and downstream (Fig. 1), based on substrate types. Fish samples were collected at eleven sampling sites: five at upper-, three at middle- and three at downstreams using 12 Volt electricshocker and nets with 0.5,

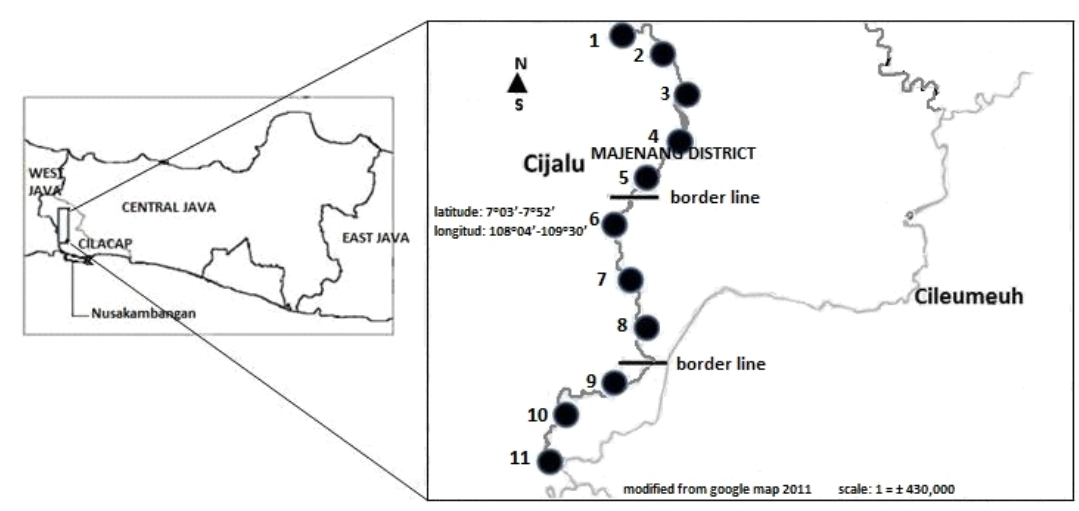

Figure 1 Sampling sites across Cijalu River (108 $04^{\prime}$ and $109^{\circ} 30^{\prime}, 7^{\circ} 03^{\prime}$ and $\left.7^{\circ} 52^{\prime}\right)$ Notes : $1-11=$ sampling site numbers — $=$ border among river's parts 
Table 1 Physico-chemical parameters measurement methods

\begin{tabular}{ll}
\hline Physico-chemical parameter & Measurement methods \\
\hline Water depth $(\mathrm{m})$ & Sechi disk \\
Light intensity $(\mathrm{m})$ & Sechi disk \\
Water temperature $\left({ }^{\circ} \mathrm{C}\right)$ & Thermometer \\
Water $\mathrm{pH}$ & Universal pH papers \\
Carbon dioxide $\left(\mathrm{CO}_{2}\right)$ & APHA 1985 \\
Water velocity $(\mathrm{m} / \mathrm{sec})$ & Linear measurement \\
Substrate & Visual \\
\hline
\end{tabular}

0.75 and 1 inch in mesh sizes. Sampling was performed from April to July 2012. Electricshocker and 0.5 inch nets were used during the sampling in the upper-stream, whereas 0.75 and 1 inch nets were used at the middle- and downstreams. Sampling efforts were performed for one hournetting and electroshocking at each site.

Biological variables and physico-chemical characteristics were examined during the study. Biological variables measured were number of fish species (S) and fish distribution in Cijalu River. Physico-chemical parameters measured were water depth, light intensity, water temperature, water acidity $(\mathrm{pH})$, carbon dioxide, water velocity and river substrate. Methods used in measuring physico-chemical parameters are summarized in Table 1.

Fresh fish samples were directly preserved in labelled plastics bag filled with $70 \%$ ethanol. D irect fixation using ethanol was carried out due to technical difficulties in obtaining formalin. Upon arrival in the laboratory, the samples were washed under running water and the used soaking ethanol was replaced by the fresh $70 \%$ ethanol. For permanent preservation, the samples were fixed inside bottles containing fresh $70 \%$ ethanol (diluted from 100\% pro-analysis ethanol). Samples were identified according to identification key from Kottelat $\notin \mathrm{al}$. (1993) and FishBase (Froese \& Pauly 2012).

\section{RESULTS AND DISCUSSION}

\section{Species Diversity}

A total of 19 fish species of 10 families were found during sampling at Cijalu River (Table 2) which is considered as high diversity based on guidelinefrom NCD ENR (2006).

This study found lower number of species (19) compared to previous study in Cimanuk River which found 40 species (Sjafei $\notin$ al. 2001). Cimanuk River was chosen as the comparison because Cimanuk River is located in the same biogeographic region and is in the same island with Cijalu River. Different results between this study at Cijalu River and the study at Cimanuk River could be caused by different ecological characteristics such as river length, river size and annual water volumes. Based on survey at Cijalu River in 2012 and at Cimanuk River in 2011 (Nuryanto \& Sugiharto 2011), Cijalu River is shorter and smaller than Cimanuk River. Cijalu River is only about $40 \mathrm{~km}$ in length, spanning only from northern to southern part of Majenang District in Cilacap Regency, whereas Cimanuk River has more than $100 \mathrm{~km}$ in length spanning from $G$ arut Regency up to the offshore of Java Sea in Indramayu Regency, West Java Province. Moreover, Cijalu River is approximately $40 \mathrm{~m}$ in width, while Cimanuk River reaches $100 \mathrm{~m}$ in width at the lower part. In addition, Cimanuk River has more constant annual water volumes than Cijalu River. According to Kottelat \& al. (1993) longer and wider ecosystems are usually assumed to have higher microhabitat variation than smaller and shorter areas. High habitat variation supports high variety of inhabitants. Therefore, it is reasonable that Cimanuk River which is longer and wider than Cijalu River has high number of species. These conditions agree with Wootton (1991) who noted that larger streams are inhabited by higher number of species due to higher microhabitat variety than the smaller one. Similar phenomenon was also reported by Clavero \& al. (2004) in 27 Iberian Mediterranean river basins, where wider rivers (Tajo, Guadiana and Jucar Rivers) supported higher number of fish species than the remaining twenty four smaller rivers. In addition, Mazeika e al. (2006) reported that stream geomorphic, including stream size, has significant effect on fish community diversity. 
Table 2 Fish species and distribution at Cijalu River

\begin{tabular}{|c|c|c|c|c|c|}
\hline \multirow{2}{*}{ No } & \multirow{2}{*}{ Family } & \multirow{2}{*}{ Species } & \multicolumn{3}{|c|}{ Distribution } \\
\hline & & & Upper & Middle & Lower \\
\hline 1 & Anabantidae & a. Anabastestudinas & - & - & + \\
\hline \multirow{3}{*}{2} & \multirow{3}{*}{ Bagridae } & a. Mystus galio & - & + & + \\
\hline & & b Mystus micacanthus & - & + & + \\
\hline & & C Heribagnusnemmus & - & + & + \\
\hline 3 & Balitoridae & a. Nemadhilus fasiatus & - & + & + \\
\hline \multirow{2}{*}{4} & \multirow{2}{*}{ Channidae } & a. Channa striata & & + & + \\
\hline & & b Channa gadua & + & - & - \\
\hline 5 & Cichlidae & a. Oreodramisnildtias & - & + & - \\
\hline \multirow{6}{*}{6} & \multirow{6}{*}{ Cyprinidae } & a. Labidbarbuskublii & - & + & + \\
\hline & & b Mystadeuas detusinostris & - & + & + \\
\hline & & C Osteochilus vittatus & - & + & + \\
\hline & & d Barbodesbindatus & + & + & + \\
\hline & & e Barbodesmicrops & - & + & + \\
\hline & & f. Rasbora argyrdaenia & + & + & + \\
\hline 7 & Loricariidae & a. Pterygoplidhthysparcalis & - & + & + \\
\hline \multirow{2}{*}{8} & \multirow{2}{*}{ Osphronemidae } & a. Osphronems garramy & - & + & - \\
\hline & & b Tridopodustridopterus & - & + & + \\
\hline 9 & Poeciliidae & a $\quad$ Poceilia reticilata & + & + & + \\
\hline 10 & Sisoridae & a. Glyptohorax platypogon & + & - & - \\
\hline
\end{tabular}

Notes: - $=$ Absent; $+=$ present

Species diversity comparison to the studies outside Indotropic or O riental Region showed complex pattern of similarities and differences. For example, our study obtained similar number of species with a study carried out by Clavero $\&$ al. (2004) in G uadalquivir Rivers. However, different phenomena were observed when comparing our study to other studies. In one hand, our species record in Cijalu River was lower compared to the study reported by Clavero $\&$ al. (2004) conducted in three Iberian Mediterranean river basins. On the other hand, a slightly higher species number was recorded in our study compared to a study reported by Cassatti (2005) from the Morno do Diabo State Park, southeastern Brazil. O ur result also recorded higher species number than the collection reported by Clavero $\boldsymbol{\notin} \mathrm{al}$. (2004).

The above comparisons were not equal since our study and those studies from Clavero $\notin \mathrm{al}$. (2004) and Cassatti (2005) were located in different biogeographic regions. These differences might cause different inhabitants. Therefore, it is reasonable to find that results on fish species composition from our study conducted in Indotropic or Oriental Region showed different results from the studies conducted in Brazil (Neotropic Region) and Europe (Palearctic Region). According to Gaston and Williams (1997), each biogeographic region has their own organisms and most of the organisms are different among regions.

This study at Cijalu River found 10 families i.e. Anabantidae, Bagridae, Balitoridae, Channidae, Cichlidae, Cyprinidae, Loricariidae, Osphronemidae, Poeciliidae and Sisoridae. Cyprinidae was the most speciose family with 6 species, followed by Bagridae with 3 species, and then Channidae and Osphronemidae with two species, respectively. The remaining six families only had one species, respectively (Table2).

Comparison on family level also showed similarities and differences among studies. Our study at Cijalu River recorded lower number of families compared to a study conducted at Cimanuk River which recorded 20 families (Sjafei $\notin$ al. 2001). This difference could be caused by different ecological characteristics as previously discussed. However, both studies agreed on Cyprinidae being the most speciose family. High number of cyprinids species was also reported from Musi River, Kejalo Curup, Bengkulu with seven species (D uya 2008).

It seems that high number of Cyprinids species is a common phenomenon in the river systems. This phenomenon was also reported in previous studies at different river systems either in Indonesia or outside Indonesia. In Rawa 
Lebak Rungan River there were 19 Cyprinidae species recorded (Sulistyarto \&al. 2007). A number of 26 cyprinids species was recorded in Bukit Batikap, Central Kalimantan (Haryono 2002), while a study in Kayan Mentarang National Park, East Kalimantan recorded 19 species of Cyprinidae (Haryono 2004). In Java Island, several studies also found various numbers of cyprinids species. All studies reported that Cyprinidae is the dominant family (Cileumeuh River (Nuryanto eal. 2012); Cikawung River (Nuryanto \& al. 2015)). Our present study and those previous studies agree with Nguyen and De Silva (2006) who reported that cyprinid group dominated freshwater fish species in Asia. Ahmad eal. (2014) also reported that Cyprinid dominated fish species in Sungkai Wildlife Reserve. The dominance of Cyprinidae was also reported in the river basins throughout Europe (Reyjol \&al. 2007). However, the trend of Cyprinidae dominance was not observed in southeastern Brazil where the speciose familiy were Characidae followed by Cichlidae and Loricariidae; there were no Cyprinid species recorded in southeastern Brazil (Langeani e al. 2005). It was not possible to compare this study at Cijalu River with the study conducted in the Iberian Mediterranean rivers at family level, because there was no family information available in the Iberian Mediterranean rivers study (Clavero $\notin \mathrm{al}$. 2004). As it was discussed previously, the different results were caused by these studies being conducted in different biogeographic regions. However, the comparison itself is important to enrich our knowledge of other taxa (species and family) occurred in other biogeographic regions.

Another important information resulted from this study was that 3 of 19 species found were non-native or introduced or exotic species i.e. Pterygpdidthysparcalis(Page \& Robins 2006; Levin eal. 2008), Poeiliaretiaulataand O. nildtias(Paller \& al. 2011). Therefore, high species diversity at Cijalu River could not be used as an indicator of river health because it is inhabited by three exotic species which might become problem for native species, although Maitland (2004) stated that if the number of exotic species is less than $25 \%$, the ecosystem is still in healthy condition.

Nevertheless, we have to be aware of the presence of P. pardalis and O. nildiaus in Cijalu River because it may become a major problem in the future. It has been reported by Maitland (2004) and Pimentel \&al. (2005) that exotic species might threaten native species through ecological alteration. Moreover, introduced species has caused native species declining in numbers due to competition, disease transmission etc. (Gozlan eal. 2010). Previous studies had shown negative impact of introduced species. Hermoso $\notin$ al. (2011) reported that the declining numbers of native species in Iberian Streams was due to high abundance of exotic species. A study from Albins and Hixon (2008) had also shown a negative impact of exotic species on native species with $79 \%$ average value of reduction. It has been reported that nile tilapia becomes competitor in an ecosystem (Cagauan 2007) or predator for native species (Morgan \& al. 2004). Nile tilapia wins the competition because this species is more aggressive and voracious (Morgan $\notin$ al. 2004). A study from Hoover $\notin$ al. (2004) has also reported a negative impact of $\mathrm{P}$. pardalis to native species in USA waters. In Indonesia, Yuniartiningisih (2011) has reported that nile tilapia has caused $\mathrm{R}$ argyrdaeniaand $\mathrm{R}$ lateristriata to be declining in numbers in Pelus River, Purwokerto, Central Java Province. This decrease was due to niche overlap among those species.

In case of Cijalu River, high awareness should be paid because introduced species have higher biological advantages than those of native species, so they can better adapt to aquatic habitat with poor water quality than that of native species. For instance, mouth sucker catfish (P. pardalis) lives well in aquatic ecosystem with low oxygen content because this species is equipped with arborescent organ for effective respiration in such ecological condition. This species is also well adapted to aquatic ecosystems with high organic matter content because it feeds on detritus and algae (Page \& Robin 2006). Whereas, nile tilapia (O. nildias) is well adapted to poor water quality ecosystems (Figueredo \& Giani 2005). Therefore, it is necessary to control the developmenet of $\mathrm{P}$. pardalis and $\mathrm{O}$. nildias population in Cijalu River to minimize the threat to native species.

\section{Fish Distributions}

Five species was collected at the upperstreams. These species were Barbodes bindatus, Rasbara argyrdaenia, Poeilia retiaulata, Channa gadura and Glyptothorax platypogon Sampling conducted at the middle part of Cijalu River 
obtained a total of 16 fish species. The obtained species were Pterygodidhthys pardalis, Mystus gulio, Mystusmiaracanthus, Hemibagusnemus, Hemibagus nemus, Tridhopodus trichoptens, Chama striata, Oreothromisnildtias, Labidbanbuskuhlii, Mystadeuas dotusirostris Barbodks bindatus, Barbodes microps, Osteohilus vittatus, Rasbora argyrdaenia, Poeilia retiulata and Osphronemus gouramy. At the downstream area, a total of 15 fish species was found during the study, i.e. Pterygpdidhthys pardalis, Mystus gulio, Mystus micacanthus, Hemibagus nemuns, Nemadhilusfasciatus, Tridhopodustrichopterus, Channa striata, Labidbandus kuhlii, Mystadaus dotusirostris, Barbodes bindatus, Barbodes micops, Osteorilus vittatus, Rasbora argyrdaenia, Pceilia reticulata and Anabastestudinas

It seems that different species compositions were observed in each river part. There was also a tendency that some species only occurred at certain part of the river, such as G. platypogon in upper-stream and A. testudinas in down-streams areas; while the other species were widely distributed at most river parts, such as L. kuhlii and $\mathrm{M}$ dotusirostris or even along the river i.e. B. bindatus and R. argyndaenia (Table 2). This complex distribution pattern could be caused by some species having specific preference to certain ecological condition, while the other species can adapt to a wide range of ecological factors. For example, G. platypogonpreferred upstream area of the river with stong current and stony substrate. G. platypogonis equipped with ventral disc to attach itself on the substrate in strong current upperstream area.

Typical downstream species, Anabas testudinas were found. The finding was already assumed before sampling since several ecological characteristics observed at the lower part of Cijalu River, such as average water temperature ranged from 28 to $30^{\circ} \mathrm{C}, \mathrm{pH}$ ranged from 5.7 to 6.8 , carbon dioxide ranged between 0.1 and $0.5 \mathrm{ppm}$, as well as muddy and sandy substrates, fit well with the need of that species. This species adapted to poor aquatic habitat since it is equipped with arborescent organ for effective respiration in such ecological condition. This finding was congruent with the finding from Tay $\&$ al. (2006) who reported that A. tetudinasinhabits swamp areas, stagnant water bodies, estuaries and ponds.

The finding of $\mathrm{B}$. bindatus along part of the river was not surprising since this species normally inhabits wide range of habitats from strong to weak current. A similar finding was also reported in Cileumeuh River (Nuryanto \& al. 2012) and Cikawung River (Nuryanto \&al. 2015). B.bindatus commonly inhabits mountain stream, river and lake. This means that $\mathrm{B}$. bindatus can adapt to a wide range of habitat conditions.

The remaining Cyprinidae species was found at middle- and downstream of Cijalu River, ranging from stone to sandy bottom and from high to low water velocity. This means that Cyprinids species were distributed in all parts of the river. The finding was normal since it is agreed with the finding from Nikolsky (1963) who has noted that Cyprinidae commonly inhabits river with either high or low velocity.

A typical upstreams species G. platypogonwere found during the sampling. This result was different to Nuryanto \& al. (2012; 2015) who did not find G. platypogon in Cileumeuh and Cikawung Rivers. The difference could be caused by different fishing gear used to collect samples at the upstream areas in the present and previous studies. In the present study, we used electricshocker during sampling at the upstream, while Nuryanto $\&$ al. (2012; 2015) only used nets. Both sampling gears had different effectiveness to be used at the upstream area. Electricshocker is more effective than nets because electricshocker can induce fish in any water velocity conditions and in any fish-hiding places. The electricity induction caused fish to become weak and easily to be caught. In contrast, strong current at upstream area washed away the nets before even trapping fishes. According to Lapointe $\notin a \mathrm{al}$. (2006), sampling effectivity at each part of a river depends upon the fishing gear, while electricshocker is the best gear for fish sampling at upstream area.

Mystusnigicepsand $\mathrm{H}$. nemurus(Bagridae) were only found at the middle and lower parts of Cijalu River. In another study conducted at Serayu River, it has been reported that Mystusnigicessand $H$. nemus were distributed along the river (Setijanto \& Sulistyo 2008). The difference could be due to different microhabitat of Cijalu and Serayu Rivers. Cijalu River has many plain or flat and shallow areas with sandy substrates, while Serayu River has many sites with swampy and deep areas with muddy susbtrates (Nuryanto \& Sugiharto 2011). These types of habitats in Serayu River most likely are the reason that both bagrids species were distributed along Serayu River. 
Table 3 Average value of physico-chemical characteristics of Cijalu River

\begin{tabular}{lccc}
\hline Physico-chemical characteristic & Upper & Middle & Lower \\
\hline Depth $(\mathrm{m})$ & 0.66 & 0.48 & 0.60 \\
Light intensity $(\mathrm{m})$ & 0.47 & 0.35 & 0.39 \\
Temperature $\left({ }^{\circ} \mathrm{C}\right)$ & 28.0 & 27.0 & 30.0 \\
Velocity $(\mathrm{m} / \mathrm{s})$ & 1.47 & 0.67 & 0.33 \\
Acidity $(\mathrm{pH})$ & 6.80 & 6.3 & 5.7 \\
Carbon dioxide $\left(\mathrm{CO}_{2}\right)(\mathrm{ppm})$ & 0.1 & 0.5 & 0.3 \\
Substrate & Big to medium stones & Small stones to gravel & Sand to mud \\
\hline
\end{tabular}

\section{Physico-chemical Characteristics}

Average values of physico-chemical parameters in Cijalu Rivers are presented in Table 3. Water velocity and substrates were the two parameters showing quite differences among parts of Cijalu River; while the remaining parameters were almost similar among parts of the river. Therefore, the discussion focused on species distribution comparison was based on those two parameters.

The differences on water velocity and substrates were suggested to be responsible for different fish distribution pattern along the river. It has been well known that water velocity or current is a key factor causing differences among river parts (Odum 1971) affecting distribution, movement and adaptive behaviour of riparian organisms (Brown 1975). In this study, G. platypognand C. gadua were found only at the upper part of the river with high water velocity and stony substrate. This may be due to the adaptation capability of these species to river part which has strong current and stony substrate. According to $\mathrm{Ng}$ and Rachmatika (2005) Glyptthorax is able to survive in strong water current because it is equipped with thoracic adhesive organ, so that it can attach on stony substrate. Whereas, C. gaduais adapted to strong current and stony substrate by hiding inside crevices or between stones.

The finding of P. pardalis T. tridgpterus and A. testudnasin the middle and lower parts of Cijalu River agreed with our expectation since those three species can adapt to water ecosystem with low oxygen content, high carbon dioxide, low acidity and muddy substrate. This finding was in agreement with that of Pethiyagoda (1991) stating that A. testudineusis well adapted to poor habitat quality. T. tidhqterus inhabits swamps areas and ponds with high density of freshwater vegetations (Low \& Lim 2012). In addition, Pethiyagoda (1991) reported that P. pardalis, T. tridgptensand A. testudinas are able to live in poor habitat because they have the ability to directly breathe oxygen from the air using additional respiratory organ. The remaining species were not specific-site, so they were distributed almost along the river. Their distribution along parts of the rivers is well supported by ecological characteristics which are relatively moderate, especially water velocity.

\section{CONCLUSIONS}

Nineteen fish species of 10 families were collected during the study at Cijalu River, which indicated that the river has high fish diversity. Cyprinidae is the speciose family with six species. Some species were distributed along the river, while other species were limited at certain parts of the rivers. The difference in species distribution could be due to various physicochemical characteristics along parts of the river, especially watervelocity and substrate.

\section{ACKNOWLEDGEMENTS}

We would like to thank Jenderal Soedirman University for the funding. We greatly appreciated students who were involved during the sampling and laboratory works. We also greatly appreciated fishermen and driver for their help during the study. 


\section{REFERENCES}

Ahmad AB, Fahmi-A hmad M, Rizal SY. 2014. Fish diversity in small streams of Sungkai Wildlife Reserve, Perak, Malaysia. JWildlife and Park 29:13-21.

Albaret JJ, Simier M, D arboe FS, Jean-Marc E, Raffray J, de Morais LT. 2004. Fish diversity and distribution in the Gambia Estuary, West Africa, in relation to environmental variables. Aquat Living Resour 17(1): 35-46.

Albins MA, Hixon MA. 2008. Invasive Indo-Pacific lionfish Ptecismolitans reduce recruitment of Atlantic coralreef fishes. MarEcol Prog Series 367:233-8.

American Public Health Association (APHA). 1985. Standard mothods for the examination of vater and vastevater $16^{\text {th }}$ eelition Washington. USA.

Brown VM. 1975. Fishes. In: StudiesinEadogy: RivesE Edogy. Edited by Whitton BA. Boston (US): Blackwell Scientific Publication.

Cagauan AG. 2007. Exotic aquatic species introduction in the Philippines for aquaculture - a threat to biodiversity or a boom to the economy? J Environ Sci Manage 10(1):48-62.

Cassatti L. 2005. Fish assemblage structure in a first order system, southwestern Brazil: longitudinal distribution, seasonality, and microhabitat diversity. Biota Neotropica 5(1):75-83.

CBD (Convention on Biological Diversity). 2003. Statusand Trends of Biodivesity of InlandWater Ecosystens CBD Technical Series No 11.p116.

Clavero M, Blanco-Garrido F, Prenda J. 2004. Fish fauna in Iberian Mediterranean river basins: biodiversity, introduced species and damming impacts. Aquatic Conserv Mar Freshw Ecosystem 14:575-85.

Coates D, Poeu O, Suntornaratana U, Tung NT, Viravong S. 2003. Biodiversity and fisheries in the Lower Mekong Basin. MekongD evelopment Series 2:30.

Collares-Pereira MJ, Coelho MM, Cowx IG. 2002. Conservation of Freshnater Fishes Options for theFuture Oxford (UK): Fishing News Books Ltd. p 462.

Dudgeon D, Arthington AH, Gessner MO, Kawabata ZI, Knowler DJ, Leveque C, Naiman RJ, Prieur-Richard AH, Soto D, Stiassny MLJ, Sullivan CA. 2006. Freshwater biodiversity: importance, threats, status and conservation challenges. Biol Rev 81:163-82.

Duya N. 2008. Ichtyofauna in Musi River Kejalo Curup Bengkulu. Jurnal G radien 4(2):394-6.

Figueredo CC, Giani A. 2005. Ecological interactions between Nile tilapia (OreohromisnildiasL.) and the phytoplanktonic community of the Furnas Reservoir(Brazil). Fresh Biol 50:1391-403.

Froese R, Pauly D. [Internet]. 2012. FishBase. Stockhlom (SE): World Wide Web Electronic Publication; [updated 2012 Sept]. Available from: www.fishbase.org
Gaston KJ, Williams PH. 1997. Spatial pattern to taxonomic diversity. In: G aston KJ, editor. Biodiversity, A bidogy of numbers and differene (seeond eeition). Cambridge (UK): Blackwell Science, Cambridge University Press. p 202-29.

Gozlan RE, Britton JR, Cowx I, Copp G H. 2010. Current knowledge on no-native freshwater fish introductions.J Fish Biol 76:751-86.

Harrison TD, Whitfield AK. 2006. Estuarine typology and the structuring of fish communities in South Africa. Environ Biol Fish 75:269-93.

Haryono. 2002. Fish species diversity and related aspect Kayan Mentarang National Park river basin East Kalimantan. In: Fish Seminar II and First Indonesian Ichthyologist Association Congress. Proceedings: 2002 October 22-23; Bogor. Indonesia.

Haryono. 2004. Cyprinids fish community in aquatic habitat around Bukit Batikap Muller Mountain Central K alimantan. Jurnal Iktiologi Indonesia 4(2):79-84.

Hermoso V, Clavero M, Blanco-Garrido F, Prenda J. 2011. Invasive species and habitat degradation in Ibreian streams: an analysis of their role in freshwater fish diversity loss. EcolApplic 21(1):175-88.

Hoover J, Killgore J, Cofrancesca A. 2004. Suckermouth catfishes: threats to aquatic ecosystems in the United States?ANSRP Bulletin 04(1):1-9.

Kar D, Nagarathna AV, Ramachandra TV, D ey SC. 2006. Fish diversity and conservation aspects in an aquatic ecosystem in Northeastern India. Zoos' Print J 21(7):2308-15.

Kottelat M. 2012. Conspectus cobitidum: an inventory of the loaches of the world (Teleostei: Cypriniformes; Cobitoidei). Raffles Bull Zool 26 (Suppl):1-199.

Kottelat M, Whitten AJ, Kartikasari SN, Wirjoatmojo S. 1993. Fredmater Fishes of Westem Indonesia and Sulawes. Jakarta(ID ): C.V.Java Books.

Langeani F, Cassatti L, Gameiro HS, do Carmo AB, RossaFeres D de Ceruiera. 2005. Riffle and pool fish communities in a large stream of southeastern Brasil. Neotropical Ichtyology:305-11.

Lapointe NWR, Corkum LD, Mandrak NE. 2006. A comparison of methods for sampling fish diversity in shallow offshore waters of large rivers. North Am J Fisheries Manage 26:503-13.

Leveque C. 1997. Biodiversity Dynamics and Conservation: The Freshuater Fish of Tropical Africa Cambridge (UK): Cambridge University Press.

Leveque C, O berdorff T, Paugy D, Stiassny MLJ, Tedesco PA. 2008. Global diversity of fish (Pisces) in freshwater. Hydrobiologia 595:545-67.

Levin BA, Phuong PH, Pavlov D S. 2008. D iscovery of the Amazon sailfin catfish Pterygolidhthys pardalis (Castelnau, 1855) (Teleostei: Loricariidae) in Vietnam. J Appl Ichthyol 24:715-7. 
Low BW, Lim KKP. 2012 Gouramies of the genus Tridhopodus in Singapore (Actinopterygii: Perciformes: O sphronemidae). Nature in Singapore 5:83-93.

Maitland PS. 2004. Evaluating the ecological and conservation status of freshwater fish communities in the United Kingdom. In: Scottish Natural Heritage Commissioned Report No. 001 (ROAME No. F01AC6). p 88.

Mazeika S, Sulivan SM, Watzin MC, Hession WC. 2006. Influence of stream geomorphic condition on fish communities in Vermont, USA. Freshw Biol 51:1811-26.

Morgan DL, Gill HS, Maddern MG, Beatty SJ. 2004. Distribution and impact of introduced freshwater fish species in Western Australia. NZ J Mar Freshw Res 38(3):511-23.

$\mathrm{Ng} \mathrm{HH}$, Rachmatika I. 2005. Glyptothorax exodon a new species of rheophilic catfish from Borneo (Teleostei:Sisoridae). Raffles BullZ ool53(2):251-5.

Nguyen TTT, De Silva SS. 2006. Freshwater finfish biodiversity and conservation: an Asian perspective. Biodiv Conserv 15:3543-68.

Nikolsky GV. 1963. TheEcoloy of Fishes Translated from Russian by L. Birkett. London (UK): Academic Press.

North Carolina D epartment of Environment and Natural Resources (NCDENR). 2006. Standard Operating ProcedureBidogial Monitoing StreamFish Commuity Assessment Program North Carolina (USA): Department of Environment and Natural Resources.

Nuryanto A, Bhagawati D, A bulias MN, Indarmawan. 2012. Fish diversity at Cileumeuh River in District of Majenang, Cilacap Regency, Central Java. Jurnal Iktiologi Indonesia 12(2):147-53.

Nuryanto A, Bhagawati D, Abulias MN, Indarmawan. 2015. Fish fauna in Cileumeuh River, Cilacap Regency, Central Java. Jurnal Iktiologi Indonesia 15(1):25-37.

Nuryanto A, Sugiharto. 2011. Population genetics of the highly exploited bagrid fish Hemibagus nemmus in Java Island: importance for conservation. Reserch Report. Purwokerto (ID ): Faculty of Biology Jenderal Soedirman University. (unpublished).

Odum EP. 1971. Piniples of Edogy, First Edition London (UK):W.B. Saunders Company.

Page LM, Robins RH. 2006. Identification of sailfin catfishes (Teleostei:Loricariidae) in Southeastern Asia. RafflesBull Zool54(2):455-7.
Paller VGC, Labatos Jr BV, Lontoc BM, Matalog OE, Ocampo PP. 2011. Freshwater fish fauna in watershed of Mt. Makilling Forest Reserve, Laguna, Philippines. PhilippineJ Sci 140(2):195-206.

Pethiyagoda R. 1991. Freshmater Fishes of Si Lanka Colombo (LK): The Wildlife Heritage Trust of Sri Lanka, Colombo.

Pimentel D, Z uniga R, Morrison D. 2005. Update on the environmental and economic costs associated with alien-invasive species in the United Species. Ecol Econ 52(3):273-88.

Reyjol Y, Hugueny B, Pont D, Bianco PG, Beier U, CaiolaN, Casals F, Cowx I, Economu A, Ferreira T, Haidvogl G, Noble R, de Sosta A, Vigneron T, Virbickas T. 2007. Pattern in species richness and endemism of European freshwater fish. Global Ecol Biogeog 16:65-75

Setijanto, Sulistyo I. 2008. Habitat preference and spatial distribution of Mystus nigiceps at the Serayu catchment area. In: National Seminar. Proceedings: 2008 November 17-18; Lampung. Lampung (ID): University of Lampung. p 168-75.

Sjafei DS, Wirjoatmodjo S, Rahardjo MF, Susilo SB. 2001. Ichthyofauna at Cimanuk River West Java. Jurnal Iktiologi Indonesia 1(1):1-6.

Sulistyarto B, So edharmaD, Rahardjo MF, Sumardjo. 2007. The impact of climate on fish species composition and abundance in Rawa Lebak, Rungan River, Palangkaraya, Central Kalimantan. Biodiversitas 8(4):270-3.

Tay YL, Loong AM, Hiong KC, Lee SJ, Tng YYM, Wee NLJ, Lee SML, Wong WP, Chew SF, Wilson JM, Ip YK. 2006. Active ammonia transport and excretory nitrogen metabolism in the limbing perch, Anabas testudimess during 4 days emersion or 10 minutes of forced exercise on land.J Exp Biol 209:4475-89.

United Nation Environmental Program (UNEP). 1987. Our Common Future Geneva (CH): The World Commission on Environment and Development Commission for the Future.

Welcomme RL. 2000. Fish biodiversity in floodplains and their associated rivers. In: G opal B, Junk WJ, D avis JA, editor. BiodivesityinWetlands Assessmet, Fundion and Conservation, Vdume1. Leiden (NL): Backhuys Publishers. p 61-87.

Wootton RJ. 1991. Edogyof TdeestFishes, FishandFisheres1. London (UK): Chapman \& Hall.

Yuniartiningsih S. 2011. Analysis of ecological impact of introduced species on Cyprinidae diversity. Master Thesis Purwokerto (ID): Postgraduate Program of Jenderal Soedirman University. 